\title{
Further Characterization of Human Colostral Antioxidants: Identification of an Ascorbate-Like Element as an Antioxidant Component and Demonstration of Antioxidant Heterogeneity
}

\author{
E. S. BUESCHER, S. M. McILHERAN, AND R. W. FRENCK \\ Department of Pediatrics and the Program in Infectious Diseases and Clinical Microbiology, University of Texas \\ Medical School, Houston, Texas 77030
}

\begin{abstract}
Human colostrum manifests antioxidant properties, being capable of spontaneous reduction of cytochrome c, depletion of polymorphonuclear leukocyteproduced $\mathrm{H}_{2} \mathrm{O}_{2}$ and protection of epithelial cells from PMN-mediated detachment. These activities can be electrophoretically concentrated at either $3.5 \mathrm{kD}$ or $50 \mathrm{kD}$ dialysis membranes at mildly alkaline $\mathrm{pH}$. They are progressively lost under increasingly alkaline conditions. They are resistant to 1-mM $N$-ethylmaleimide. Examination of a series of antioxidant compounds showed that ascorbate manifests several characteristics of colostrum, being able to reduce cytochrome $\mathrm{c}$ and deplete $\mathrm{H}_{2} \mathrm{O}_{2}$, but not altering PMN-mediated HEp2 cell detachment. Addition of ascorbate oxidase to colostrum decreased its cytochrome creducing activity by more than $85 \%$, decreased its $\mathrm{H}_{2} \mathrm{O}_{2}$ depleting activity by nearly $50 \%$, but did not alter its ability to protect HEp2 cells, all suggesting heterogeneity of colostral antioxidant activities. Treatment of colostrum with an enzymatic system (xanthine + xanthine oxidase) known to destroy ascorbate's cytochrome c-reducing activity yielded paradoxical results, decreasing colostral cytochrome $c$ reduction in a dose-related manner, while increasing its $\mathrm{H}_{2} \mathrm{O}_{2}$-depleting activity. These studies demonstrate that a colostral component similar to ascorbate, a known antioxidant compound is responsible for the majority of colostral cytochrome c-reducing activity, for about half of its $\mathrm{H}_{2} \mathrm{O}_{2}$-depleting activity, and little, if any, of its protective effect on HEp2 cells. Thus, colostral antioxidant activity is heterogeneous. (Pediatr Res 25:266-270, 1989
\end{abstract}

\section{Abbreviations}

PMN, polymorphonuclear leukocyte PMA, phorbol myristate acetate

It has recently been hypothesized that human milk is antiinflammatory (1). Because the PMN plays a prominent role in the acute inflammatory response in humans, we examined the effects of human colostrum on PMN functions typically associated with its roles in acute inflammation. These studies revealed that human colostrum has significant antioxidant activity, interferes with PMN myeloperoxidase activity, and prevents in vitro de-

Received July 8, 1988; accepted October 31, 1988.

Correspondence E. S. Buescher, M. D., University of Texas Medical School, 6431 Fannin Street, Room 1.724, Houston, TX 77030.

Supported through the National Institute of Child Health and Human Development Grant HD 13021-09. tachment of epithelial cells by activated PMN (2). Subsequent studies have further characterized this colostral antioxidant activity. We describe studies that demonstrate that colostral antioxidant activity is heterogeneous, and that a component similar to ascorbate, a well-recognized antioxidant compound, is responsible in part for human colostrum's antioxidant properties.

\section{MATERIALS AND METHODS}

Unless otherwise noted, all chemical materials were obtained from Sigma Chemical Co., St. Louis, MO.

Colostrum specimens. Samples of human colostrum were collected by breast pump from mothers $1-4 \mathrm{~d}$ postpartum. The entire content from one breast was collected. Specimens were stored on ice until processed, usually within 60-90 min of collection. On some occasions, two or three small specimens from different mothers were combined to yield a single specimen. Colostrum was processed by centrifugation at $380 \times g$ for 10 min at $4^{\circ} \mathrm{C}$, followed by discarding of the cell pellet and remixing to produce acellular "whole colostrum." Colostrum was also processed by centrifugation at $81000 \times g\left(4^{\circ} \mathrm{C}, 30 \mathrm{~min}\right)$ followed by collection of the clear aqueous fraction by needle puncture of the centrifuge tube ("aqueous colostrum"). Both whole and aqueous colostrum were stored in aliquots at $-70^{\circ} \mathrm{C}$ until used.

$P M N$ purification. Human PMN were purified from heparinized venous blood using Hypaque-Ficoll, dextran sedimentation and hypotonic lysis (3).

$\mathrm{H}_{2} \mathrm{O}_{2}$-depleting activity. $\mathrm{H}_{2} \mathrm{O}_{2}$ production by either PMN or the cell-free enzymatic system of glucose + glucose oxidase (typically $10-\mathrm{mM}$ glucose plus $0.25 \mathrm{U}$ of glucose oxidase) was quantitated by measuring horseradish peroxidase-mediated oxidation of scopoletin (4). Rates of $\mathrm{H}_{2} \mathrm{O}_{2}$ production were calculated based on the amounts of peroxide produced by known amounts of glucose + glucose oxidase under standard conditions. $\mathrm{H}_{2} \mathrm{O}_{2}$-depleting activities of colostrum and ascorbate were calculated by multiplying the observed lagtime (in $\mathrm{min}$ ) by the final rate of $\mathrm{H}_{2} \mathrm{O}_{2}$ production (in $\mathrm{nmol} / \mathrm{min}$ ). The product was divided by the vol of colostrum or ascorbate added, yielding $\mathrm{H}_{2} \mathrm{O}_{2}$ depleting activity in $\mathrm{U}$ of $\mathrm{nmol} / \mu \mathrm{L}$ colostrum (or ascorbate) added.

Cytochrome c-reducing activity. Cytochrome c-reducing activity of colostrum or ascorbate was measured by quantitating the change in $\mathrm{OD}_{550}$. A vol of $750 \mu \mathrm{L}$ stock cytochrome c solution ( $1.78 \mathrm{mg} / \mathrm{mL}$ in HBSS), was combined with colostrum $(50-500$ $\mu \mathrm{L})$ plus HBSS, or ascorbate $\left(10^{-3} \mathrm{M}-10^{-4} \mathrm{M}\right)$ plus HBSS, to a final vol of $1.5 \mathrm{~mL}$. After the solution sat at room temperature for $10 \mathrm{~min}$, the $\mathrm{OD}$ was measured at $\mathrm{OD}_{550}$. Cytochrome $\mathrm{c}$ reduction was calculated in $\mathrm{nmol}$ using an extinction coefficient 
of 21.1 (5), and the reducing activity was expressed in $\mathrm{nmol} / \mu \mathrm{L}$ of colostrum added.

Physical characterization of colostral antioxidant activity. Using the methods described above, aqueous colostrum was tested for its cytochrome c-reducing activity and $\mathrm{H}_{2} \mathrm{O}_{2}$-depleting activity after each of the manipulations listed:

1) Electrophoretic concentration of antioxidant activities: electrophoretic concentration experiments used either an Isco electroconcentration apparatus (Isco, Inc., Lincoln, NE) or a laboratory-built electrophoretic concentration apparatus. Specimens of aqueous colostrum were diluted $>1: 2$ with $0.001-\mathrm{M}$ phosphate buffer of appropriate $\mathrm{pH}$ and then electroconcentrated for $2 \mathrm{Wh} /$ cuvette at $4^{\circ} \mathrm{C}$. Barrier membranes on cuvettes were dialysis membranes of either $3.5-, 12-$ to $14-$, or $50-\mathrm{kD}$ exclusion limits.

2) $\mathrm{pH}$ adjustment of colostrum: aliquots of aqueous colostrum were adjusted to appropriate $\mathrm{pH}$ by addition of either $6-\mathrm{N} \mathrm{HCl}$ or $6-\mathrm{N} \mathrm{NaOH}$. After $1 \mathrm{~h}$ at room temperature, the $\mathrm{pH}$ was readjusted to 7.4 , and the aliquots were assayed.

3) Methanol precipitation experiments: 4 parts methanol were combined with 6 parts aqueous colostrum with vigorous shaking. The precipitated protein was removed by ultracentrifugation $(81$ $\left.000 \times g, 4^{\circ} \mathrm{C}, 30 \mathrm{~min}\right)$ and the clear supernate was assayed. Aqueous colostrum diluted appropriately with water served as the control.

4)Sulfhydryl group blocking: aqueous colostrum was treated with the irreversible sulfhydryl group blocker $N$-ethylmaleimide (1 $\mathrm{mM}$ final) for 5-10 min at room temperature. Untreated aqueous colostrum and $1-\mathrm{mM} N$-ethylmaleimide in water were used as controls.

5) The antioxidants taurine (50 $\mathrm{mM})$, cysteine $(1 \mathrm{mM}), \alpha$ tocopherol $(10 \mu \mathrm{g} / \mathrm{ml})$ and ascorbate $(1-0.1 \mathrm{mM})$ were compared to colostrum by examining the capacity of each to reduce cytochrome $\mathrm{c}$ and deplete $\mathrm{H}_{2} \mathrm{O}_{2}$. Each antioxidant was also combined with colostrum and examined. For the latter experiments, colostrum diluted with an appropriate vol of HBSS was used as the control.

6) Aqueous colostrum was treated with ascorbate oxidase $(20$ $\mu / \mathrm{mL}$ final) for $3 \mathrm{~h}$ at room temperature. Ascorbate $\left(10^{-3} \mathrm{M}\right.$ final) with and without $20 \mathrm{U} / \mathrm{mL}$ of ascorbate oxidase, and untreated aqueous colostrum served as controls.

7) Diluted aqueous colostrum (10\% vol/vol final) was incubated in the presence of $188 \mu \mathrm{mol}$ of xanthine and $42 \mathrm{mU}$ of xanthine oxidase at room temperature for $20 \mathrm{~min}$. Water or 10 $\mathrm{mM}$ ascorbate were substituted for the aqueous colostrum in controls.

HEp- 2 cell assays. The effects of stimulated PMN on HEp-2 cell adherence were examined as previously described (2). In some experiments, glucose + glucose oxidase $(10 \mathrm{mM}$ final and $4.5 \mathrm{U} / \mathrm{mL}$, respectively) were substituted for PMN to examine whether $\mathrm{H}_{2} \mathrm{O}_{2}$ from activated PMN was responsible for HEp-2 cell detachment. In other experiments, $50 \%$ whole colostrum (final) or $10^{-3}-\mathrm{M}$ ascorbate (final) were included to examine protection against $\mathrm{H}_{2} \mathrm{O}_{2}$ produced by the glucose + glucose oxidase system or PMA-stimulated PMN.

Unless otherwise noted, all data shown are the mean \pm SEM.

\section{RESULTS}

Physical Characterization of Colostral Antioxidant Activity. Electrophoretic concentration of antioxidant activities. Adjustment of colostral $\mathrm{pH}$, followed by electrophoretic concentration revealed that colostral antioxidant activity was best electroconcentrated against a $3.5-\mathrm{kD}$ membrane at a $\mathrm{pH}$ of 7-9 (Table 1). Increasing the pore size of the barrier membrane in the concentration cuvette to a $50-\mathrm{kD}$ exclusion limit still allowed concentration of colostral antioxidant activity after $2 \mathrm{Wh}$ at $4^{\circ} \mathrm{C}$ (Table 2).

Effects of $p H$ adjustment on colostral antioxidant activity. Colostral antioxidant activity was stable at $\mathrm{pH} 7-9$, and at $\mathrm{pH}$ 1.5 for $1 \mathrm{~h}$ at room temperature. Increasing the $\mathrm{pH}$ to $>9$ resulted in a stepwise diminution in antioxidant activities (Table 3 ).
Table 1. Effects of pH on electrophoretic concentration of colostral cytochrome c-reducing activity

\begin{tabular}{|c|c|c|c|}
\hline \multirow[b]{2}{*}{$\begin{array}{l}\mathrm{pH} \text { of } \\
\text { diluting }\end{array}$} & \multicolumn{3}{|c|}{$\begin{array}{l}\text { nmol of cytochrome } \mathrm{c} \text { reduced } / \mu \mathrm{L} \\
\text { added }\end{array}$} \\
\hline & $\begin{array}{l}\text { Starting } \\
\text { material }\end{array}$ & $\begin{array}{c}+ \\
\text { pole }\end{array}$ & pole \\
\hline pH 5 & 0.111 & 0.609 & 0.301 \\
\hline $\mathrm{pH} 6$ & 0.168 & 0.054 & 0.581 \\
\hline $\mathrm{pH} 7$ & 0.180 & 0.036 & 1.057 \\
\hline $\mathrm{pH} 8$ & 0.135 & 0.050 & 0.962 \\
\hline $\mathrm{pH} 9$ & 0.149 & 0.057 & 0.886 \\
\hline
\end{tabular}

Table 2. Effects of membrane pore size on electrophoretic concentration of colostral antioxidant activity

\begin{tabular}{ccccc}
\hline & \multicolumn{2}{c}{$\begin{array}{c}\text { nmol cytochrome c } \\
\text { reduced } / \mu \text { L added }\end{array}$} & $\begin{array}{c}\mathrm{nmol} \\
\mathrm{H}_{2} \mathrm{O}_{2} \\
\text { depleted } \\
\mu \mathrm{L}\end{array}$ \\
\cline { 2 - 4 } Pore size & $\overline{\mathrm{x}}$ & $\mathrm{SE}$ & $(n)$ & $\begin{array}{c}\mathrm{L} \\
\text { added }\end{array}$ \\
\hline Starting material & 0.289 & 0.023 & $(8)$ & 0.202 \\
$3.5 \mathrm{kD}$ exclu- & 1.120 & 0.136 & $(6)$ & 1.484 \\
$\quad$ sion & & & & \\
$50 \mathrm{kD}$ exclusion & 1.350 & 0.126 & $(2)$ & 1.211 \\
\hline
\end{tabular}

Table 3. Effects of pH on colostral antioxidant activity*

\begin{tabular}{|c|c|c|c|c|c|c|}
\hline \multirow{2}{*}{$\begin{array}{l}\text { Colostral pH } \\
\text { adjustment: }\end{array}$} & \multicolumn{3}{|c|}{$\begin{array}{l}\text { nmol cytochrome } \mathrm{c} \\
\text { reduced } / \mu \mathrm{L} \text { of } \\
\text { colostrum }\end{array}$} & \multicolumn{3}{|c|}{$\begin{array}{c}\text { nmol } \mathrm{H}_{2} \mathrm{O}_{2} \text { depleted } / \\
\mu \mathrm{L} \text { of colostrum }\end{array}$} \\
\hline & $\overline{\mathrm{x}}$ & $\mathrm{SE}$ & $(n)$ & $\overline{\mathrm{x}}$ & SE & $(n)$ \\
\hline None & 0.619 & 0.069 & $(6)$ & 0.932 & 0.202 & (3) \\
\hline $\mathrm{pH} 8$ & 0.544 & 0.067 & (6) & 0.843 & 0.170 & (3) \\
\hline $\mathrm{pH} 9$ & 0.466 & 0.061 & (6) & 0.660 & 0.136 & (3) \\
\hline $\mathrm{pH} 10$ & 0.291 & 0.048 & (6) & 0.478 & 0.091 & (3) \\
\hline $\mathrm{pH} 11$ & 0.148 & 0.038 & (6) & 0.296 & 0.065 & (3) \\
\hline $\mathrm{pH} 12$ & 0.097 & 0.032 & $(6)$ & 0.197 & 0.049 & (3) \\
\hline $\mathrm{pH} 1.5$ & 0.638 & & (1) & & ot done & \\
\hline
\end{tabular}

* Aqueous colostrum was adjusted to the appropriate $\mathrm{pH}$ by addition of either $\mathrm{HCl}$ or $\mathrm{NaOH}$ and kept at room temperature for $60 \mathrm{~min}$. The $\mathrm{pH}$ was then adjusted to approximately 7.4 , and the antioxidant activity was measured.

Effects of methanol precipitation and $N$-ethylmaleimide. Addition of methanol to aqueous colostrum as a protein precipitant decreased its $\mathrm{H}_{2} \mathrm{O}_{2}$-depleting activity $49 \pm 4 \%(n=3)$, compared to water-diluted colostrum controls. Treatment of aqueous colostrum with the irreversible sulfhydryl blocking agent $N$-ethylmaleimide did not alter its antioxidant activity $(99 \pm 2 \%$ of untreated colostral cytochrome c-reducing activity, $n=7$, and $100 \pm 10 \%$ of untreated colostral $\mathrm{H}_{2} \mathrm{O}_{2}$-depleting activity, $n==$ 7).

Effects of antioxidants on cytochrome $\mathrm{c} / \mathrm{H}_{2} \mathrm{O}_{2}$ assays and colostral antioxidant activity. The effects of the antioxidants $\alpha$ tocopherol, taurine, cysteine, and ascorbate were compared to the effects of colostrum on cytochrome $\mathrm{c}$ reduction and depletion of $\mathrm{H}_{2} \mathrm{O}_{2}$ (produced by glucose + glucose oxidase) (Fig. 1). Neither $\alpha$-tocopherol nor taurine spontaneously reduced cytochrome $\mathrm{c}$ or depleted $\mathrm{H}_{2} \mathrm{O}_{2}$. Cysteine spontaneously reduced cytochrome $\mathrm{c}$ in a linear fashion, but did not deplete $\mathrm{H}_{2} \mathrm{O}_{2}$. Ascorbate reduced cytochrome $\mathrm{c}$ and depleted $\mathrm{H}_{2} \mathrm{O}_{2}$ in a manner similar to that observed with colostrum. By contrast, $1 \mathrm{nmol}$ of ascorbate reduced $1.2 \pm 0.2 \mathrm{nmol}$ of cytochrome $\mathrm{c}(n=6)$ and depleted 2.3 $\pm 0.2 \mathrm{nmol}$ of $\mathrm{H}_{2} \mathrm{O}_{2}$ produced by glucose + glucose oxidase $(n$ $=7$ ).

The effects of adding each of these antioxidants to human colostrum was then examined. Addition of $\alpha$-tocopherol to co- 
A

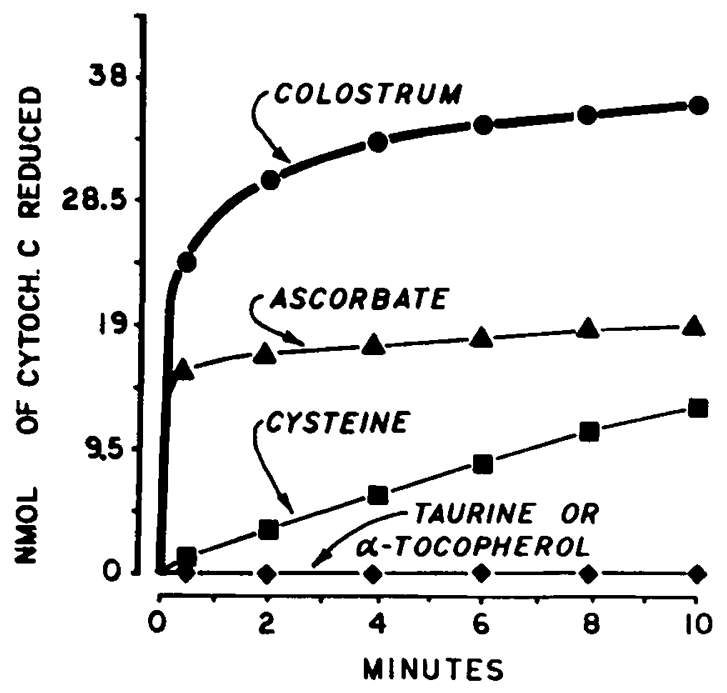

$\mathrm{B}$

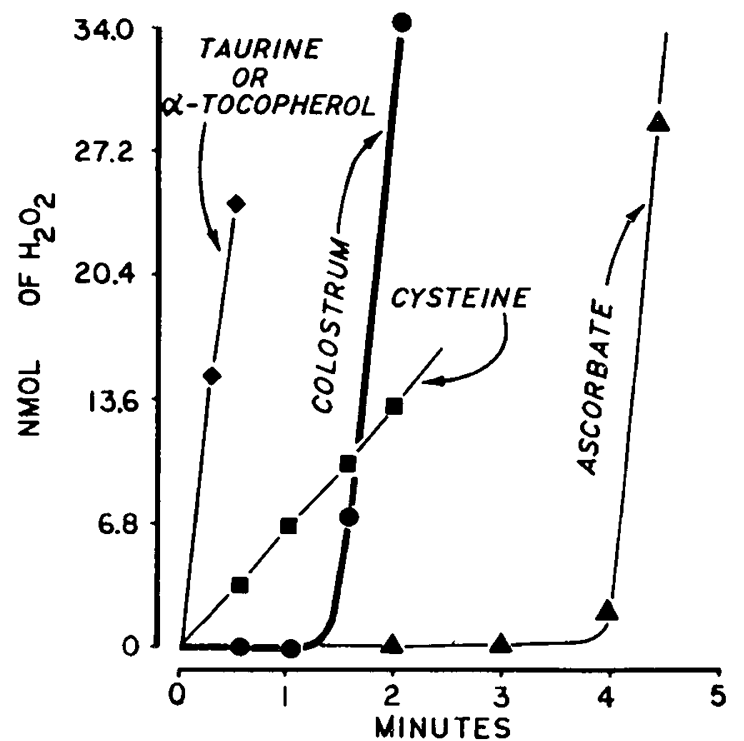

Fig. 1. Comparison of the effects of the antioxidants taurine, $\alpha$-tocopherol, cysteine, and ascorbate to the effect of colostrum on cytochrome c reduction $(A)$ and $\mathrm{H}_{2} \mathrm{O}_{2}$ depletion $(B)$.

COLOSTRUM

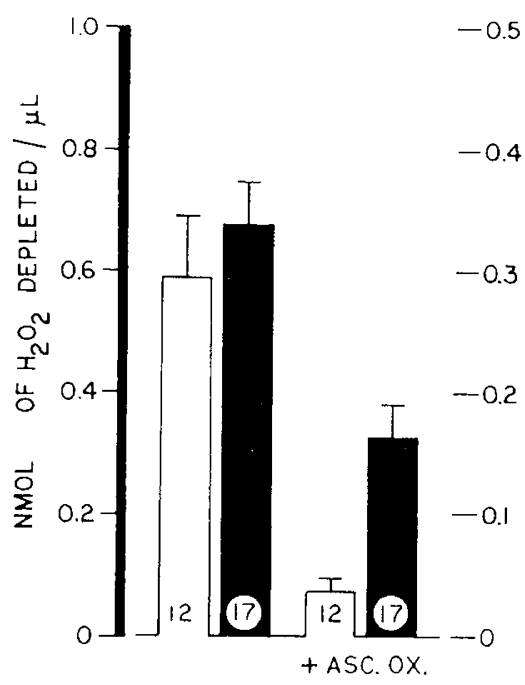

ASCORBATE

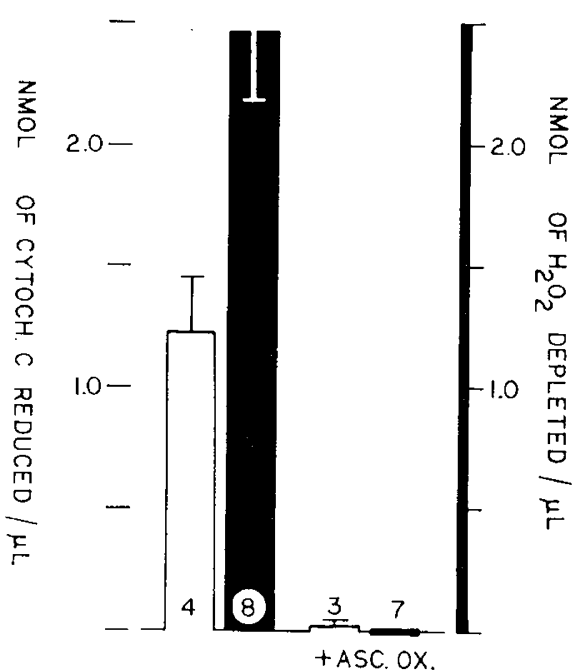

Fig. 2. The effects of ascorbate oxidase treatment on cytochrome $\mathrm{c}$ reduction (open columns) and $\mathrm{H}_{2} \mathrm{O}_{2}$ depletion (closed columns) by aqueous colostrum (left) and $1-\mathrm{mM}$ ascorbate (right). Data shown are the mean \pm SEM of the numbers of experiments shown at the base of each column.

lostrum did not alter colostrum's cytochrome c-reducing activity (107 $\pm 3 \%$ of untreated, $n=2$ ) or $\mathrm{H}_{2} \mathrm{O}_{2}$-depleting activity (102 $\pm 2 \%$ of untreated, $n=2$ ). Addition of taurine to colostrum resulted in no change in cytochrome c-reducing activity $(99 \pm$ $1 \%$ of untreated, $n=3$ ) and a slight increase in $\mathrm{H}_{2} \mathrm{O}_{2}$-depleting activity ( $123 \pm 8 \%$ of untreated, $n=3$ ). Addition of cysteine ( 1 $\mathrm{mM}$ final) to colostrum did not alter either cytochrome creducing activity $(109 \pm 2 \%$ of untreated, $n=3)$ or $\mathrm{H}_{2} \mathrm{O}_{2-}$ depleting activity ( $93 \pm 3 \%$ of untreated). Addition of ascorbate to colostrum, however, increased both its cytochrome c-reducing activity and $\mathrm{H}_{2} \mathrm{O}_{2}$-depleting activity in a dose-related fashion (data not shown).

Effects of ascorbate oxidase on colostral antioxidant activities. Treatment of aqueous colostrum with ascorbate oxidase (20 U/ $\mathrm{mL}$ ) significantly decreased both colostral cytochrome c-reducing activity $(0.295 \pm 0.051$ versus $0.039 \pm 0.008 \mathrm{nmol}$ reduced $/ \mu \mathrm{L}$ added, untreated versus treated, $<0.001$, paired sample $t$ test, $n$ $=12)$ and $\mathrm{H}_{2} \mathrm{O}_{2}$-depleting activity $(0.678 \pm 0.064$ versus 0.324 $\pm 0.056 \mathrm{nmol}$ depleted $/ \mu \mathrm{L}$ added, untreated versus treated, $p<$
0.05 , paired sample $t$ test, $n=17$ ) (Fig. 2). The decreases in each activity caused by ascorbate oxidase were both dissimilar in magnitude and incomplete, suggesting additional antioxidants might participate in each activity, particularly $\mathrm{H}_{2} \mathrm{O}_{2}$ depletion. The effect of ascorbate on cytochrome c reduction and $\mathrm{H}_{2} \mathrm{O}_{2}$ depletion was totally blocked by ascorbate oxidase.

Effects of superoxide-generating systems on colostral antioxidant activity. Treatment of colostrum with an enzymatic superoxide generating system previously described to destroy ascorbate's cytochrome c-reducing activity (6) was performed. Addition of xanthine + xanthine oxidase to colostrum resulted in dose-related decreases in spontaneous cytochrome c-reducing activity, and dose-related increases in $\mathrm{H}_{2} \mathrm{O}_{2}$-depleting activity (Fig. 3). Substitution of PMA stimulated neutrophils (as a biologic superoxide-generating system) for the enzymatic system resulted in prompt loss of both activities from colostrum.

Comparison of Colostral Antioxidants and Ascorbate. Effects of $\mathrm{pH}$ adjustment. In one experiment, 1-mM ascorbate, $\mathrm{pH} 7.3$, was aliquoted, and the $\mathrm{pH}$ of the aliquots was adjusted to 7.3- 
12 for $1 \mathrm{~h}$ at room temperature. The $\mathrm{pH}$ of each aliquot was then returned to 7.3, and cytochrome c-reducing activity was examined. At $\mathrm{pH} 7.3,0.89 \mathrm{nmol}$ cytochrome $\mathrm{c}$ were reduced/ nmol ascorbate added; at $\mathrm{pH} 9,0.87 \mathrm{nmol} / \mathrm{nmol}$; at $\mathrm{pH} 11,3.6$ $\mathrm{nmol} / \mathrm{nmol}$; and at $\mathrm{pH} 12,0.18 \mathrm{nmol} / \mathrm{nmol}$.

Electroconcentration experiments. Experiments using ascorbate in $0.001-\mathrm{M}, \mathrm{pH} 8$, buffer showed that it was concentrated at a $3.5-\mathrm{kD}$ exclusion limit membrane, but passed membranes of $12-14 \mathrm{kD}$ and more. Addition of BSA $(8 \mathrm{mg} / \mathrm{mL})$ to the ascorbate before electroconcentration functionally altered the size of the ascorbate such that it concentrated at the surfaces of membranes with $3.5-, 12-$ to $14-$, and $50-\mathrm{kD}$ exclusion limits (Table 4). In two experiments, when ascorbate + BSA was electroconcentrated then treated with ascorbate oxidase $(20 \mu /$ $\mathrm{mL}, 3 \mathrm{~h}, 25^{\circ} \mathrm{C}$ ), all cytochrome c-reducing activity of the concentrated fraction was lost.

Addition of ascorbate to colostrum. Three colostral samples were "spiked" with ascorbate to achieve a final concentration of

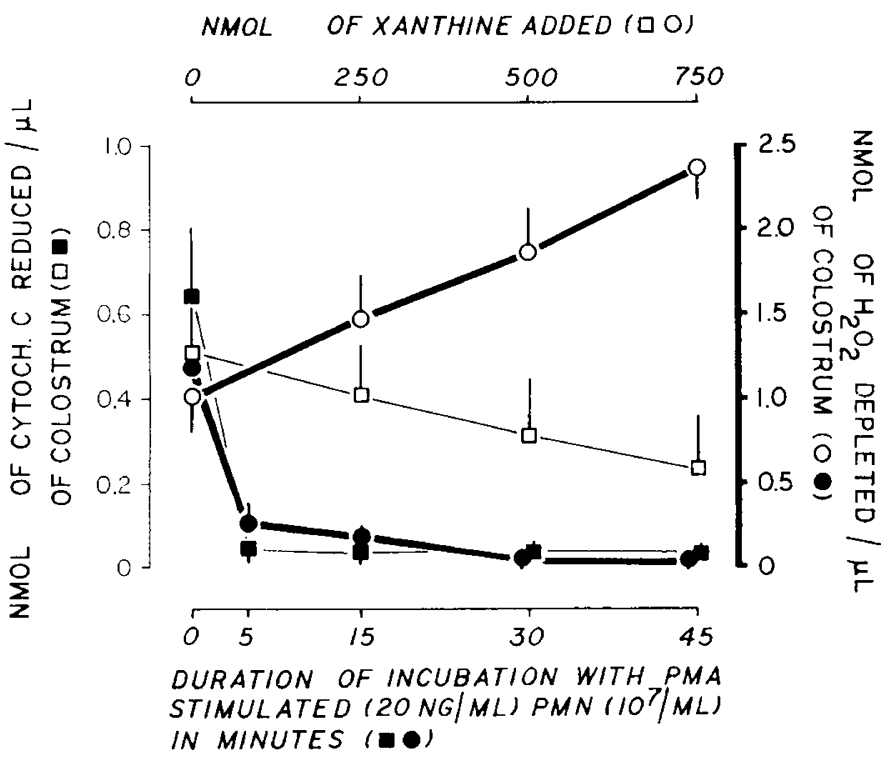

Fig. 3. The effects of two different superoxide-generating systems on colostral cytochrome c-reducing activity and $\mathrm{H}_{2} \mathrm{O}_{2}$-depleting activity. Open symbols show paradoxical effects of increasing amounts of enzymatically produced superoxide, decreasing colostral cytochrome $\mathrm{c}$ reduction, and increasing colostral $\mathrm{H}_{2} \mathrm{O}_{2}$ depletion. Closed symbols show the effects of increasing amounts of biologically produced superoxide, decreasing both colostral activities. The data are the mean \pm SEM of three separate experiments.

Table 4. Effects of membrane pore size on electrophoretic concentration of ascorbate or ascorbate $+B S A$

\begin{tabular}{|c|c|c|c|c|c|}
\hline & \multicolumn{2}{|c|}{$\begin{array}{l}\text { nmol } \\
\text { cytochrome c } \\
\text { reduced } / \mu \mathrm{L} \\
\text { added }\end{array}$} & \multicolumn{3}{|c|}{$\begin{array}{c}\text { nmol } \mathrm{H}_{2} \mathrm{O}_{2} \text { depleted } \\
\mu \mathrm{L} \text { added }\end{array}$} \\
\hline & $\overline{\mathrm{x}}$ & SE $(n)$ & $\overline{\mathrm{x}}$ & $\mathrm{SE}$ & $(n)$ \\
\hline \multicolumn{6}{|l|}{ Ascorbate } \\
\hline $10^{-4} \mathrm{M}$ & 0.108 & $0.040(2)$ & 0.167 & & $(1)$ \\
\hline $3.5 \mathrm{kD}$ membrane & 0.790 & $0.289(2)$ & 0.446 & & $(1)$ \\
\hline 12-14 kD membrane & 0.293 & $0.074(2)$ & 0.175 & & (1) \\
\hline \multicolumn{6}{|l|}{ Ascorbate + BSA $(8 \mathrm{mg} / \mathrm{ml})$} \\
\hline $10^{-4} \mathrm{M}$ & 0.130 & $0.050(2)$ & 1.623 & 0.140 & $(3)$ \\
\hline 3.5-kD membrane & 1.187 & $0.126(2)$ & $>3.996$ & $>1.055$ & (3) \\
\hline 12- to $14-\mathrm{kD}$ membrane & 1.155 & $0.088(2)$ & $>4.296$ & $>1.130$ & (3) \\
\hline 50-kD membrane & & ot done & $>5.512$ & $>0.956$ & (3) \\
\hline
\end{tabular}

* Starting material for electrophoretic concentration was $10^{-3}-\mathrm{M}$ ascorbate $+8 \mathrm{mg} / \mathrm{ml} \mathrm{BSA}$.
$1 \mathrm{mM}$, and then compared to "unspiked" colostrum with and without ascorbate oxidase treatment. Expressing the mean colostral cytochrome c-reducing activity and $\mathrm{H}_{2} \mathrm{O}_{2}$-depleting activity of these samples as $100 \%$ and $100 \%$, respectively, addition of ascorbate to the samples increased the mean activities to $899 \%$ and $362 \%$. Addition of ascorbate oxidase $(10 \mathrm{U} / \mathrm{mL}$ final $)$ to the "unspiked" colostrum samples decreased the mean activities to $29 \%$ and $60 \%$. Addition of ascorbate oxidase to the "spiked" colostral samples decreased the mean activities to $28 \%$ and $60 \%$, respectively.

HEp2 cell experiments. We had previously observed that colostrum exerted a sparing effect on HEp2 cell detachment mediated by PMA-stimulated neutrophils (2). Substitution of the enzymatic $\mathrm{H}_{2} \mathrm{O}_{2}$-producing system glucose + glucose oxidase for activated $\mathrm{PMN}$ resulted in detachment of $38 \pm 7 \%$ of $\mathrm{HEp} 2$ cells $(n=7)$, suggesting that $\mathrm{H}_{2} \mathrm{O}_{2}$ produced by the PMN may be primarily responsible for the observed effects. Addition of ascorbate to this assay system did not significantly decrease PMNmediated HEp2 cell detachment. Incubation of whole colostrum with ascorbate oxidase for $2 \mathrm{~h}$, either before addition to the HEp2 cell assay or during the assay itself, did not alter colostral protection from PMN-mediated detachment. With ascorbate oxidase treatment, $112 \pm 9 \%$ of starting cellular protein remained, compared to $114 \pm 11 \%$ when colostrum was not treated with ascorbate oxidase (both $n=5$ ).

\section{DISCUSSION}

The presence of large numbers of PMN in human colostrum without evidence of acute inflammation in the breast led us to hypothesize that colostrum might have antiinflammatory properties. Initial studies demonstrated that colostrum created a chemically reducing environment that was capable of depleting PMN-produced $\mathrm{H}_{2} \mathrm{O}_{2}$, suppressing PMN myeloperoxidase activity, and protecting epithelial cells in vitro from PMN-mediated injury. Although these studies demonstrated a significant antioxidant activity in colostrum, they did not identify the component(s) responsible for the observed activities.

To identify the antioxidant agent in human colostrum, we first examined the physical characteristics of the activity, finding that it could be electrophoretically concentrated under mild alkaline conditions. The use of barrier membranes with different exclusion limits during electrophoretic concentrations showed that the activity in colostrum had a mol wt of $>50 \mathrm{kD}$. Experiments altering colostral $\mathrm{pH}$ before examination of antioxidant activity showed that the antioxidant(s) were acid- and mild alkali-stable, but that antioxidant activity was progressively lost with increasing alkalinity. $N$-ethylmaleimide treatment suggested that the antioxidant activity was not due to free sulfhydryl groups. Methanol precipitation of colostral protein decreased the $\mathrm{H}_{2} \mathrm{O}_{2}$-depleting activity by only $50 \%$, suggesting that the activity might be heterogenous.

A series of recognized antioxidant compounds and radical scavengers were examined for their abilities to reduce cytochrome c and deplete $\mathrm{H}_{2} \mathrm{O}_{2}$ produced by glucose + glucose oxidase. Previous studies had shown that dimethyl sulfoxide, mannitol and methionine neither reduced cytochrome c nor depleted $\mathrm{H}_{2} \mathrm{O}_{2}$ (2). Examination of taurine, cysteine, $\alpha$-tocopherol, and ascorbate showed that only ascorbate caused both cytochrome $c$ reduction and $\mathrm{H}_{2} \mathrm{O}_{2}$ depletion. The kinetics of ascorbate's effects were very similar to those observed with colostrum, thus prompting further examination of ascorbate as an antioxidant component of colostrum.

Published quantitations of colostral ascorbate content, from $267 \mathrm{nmol} / \mathrm{mL}$ to $591 \mathrm{nmol} / \mathrm{mL}$ (7) were similar to the observed cytochrome c-reducing activity in aqueous colostrum, $497 \pm 47$ $\mathrm{nmol} / \mathrm{mL}$, reported in our earlier studies (2). Ascorbate is a recognized antioxidant capable of spontaneously reducing cytochrome $\mathrm{c}(6)$. Treatment of aqueous colostrum with ascorbate oxidase decreased its cytochrome c-reducing activity by $85 \%$, 
while only decreasing $\mathrm{H}_{2} \mathrm{O}_{2}$-activity by approximately $50 \%$. Treatment of colostrum with ascorbate oxidase did not alter its ability to protect HEp2 cells from PMN-mediated detachment. These results again suggested heterogeneity in antioxidant activities, with ascorbate as one of the antioxidants present.

As an alternative method for oxidizing endogenous ascorbate in colostrum, colostrum was incubated with the enzymatic superoxide-generating system xanthine + xanthine oxidase. By controlling the amounts of superoxide produced (by limiting the amounts of xanthine in the mixture), dose-related decreases in colostral cytochrome c-reducing activity were observed, again consistent with ascorbate-mediated antioxidant. However, doserelated increments in $\mathrm{H}_{2} \mathrm{O}_{2}$-activity were observed simultaneously. This paradoxical effect on $\mathrm{H}_{2} \mathrm{O}_{2}$-activity may be the result of superoxide's ability to act either as an oxidant or reductant (8). These results again suggest heterogeneity in colostral antioxidant activities. When activated PMN were used as a biologic source of superoxide, rapid decreases in both colostral cytochrome c-reducing activity and $\mathrm{H}_{2} \mathrm{O}_{2}$-depleting activity were seen, as we had previously observed (2). Whereas the neutrophil NADPH oxidase is thought to be similar to the xanthine + xanthine oxidase system in that they both produce superoxide, clearly, the pure enzymatic system is not a perfect mimic of the biologic one.

The suggestion that ascorbate or ascorbate-like colostral components are one of the antioxidant components in colostrum led us to compare the physical characteristics of each. Ascorbate showed a $\mathrm{pH}$ sensitivity pattern similar to that observed in the colostral antioxidants. With a mol wt of 176 , ascorbate should more easily pass barrier membranes with limiting pore sizes increasing from 3.5 through $50 \mathrm{kD}$. This was confirmed, but appeared incongruous with the apparent size of the electrophoretically concentratable colostral activity at $>50 \mathrm{kD}$. Addition of BSA to the ascorbate before electroconcentration functionally increased the size of the ascorbate to $>50 \mathrm{kD}$, presumably through binding to the added protein (9). We presume that either 1) ascorbate binding to large colostral proteins determines the apparent size $(>50 \mathrm{kD})$ of the ascorbate oxidase-sensitive colostral antioxidant activity; or 2) a large colostral molecule with redox characteristics similar to ascorbate and chemical structure recognized by ascorbate oxidase (10) is present in colostrum. In addition, we presume that other antioxidant components (which make up the ascorbate oxidase insensitive fraction) have sizes of $>50 \mathrm{kD}$, and are trapped at the $50-$ and $3.5-\mathrm{kD}$ membranes. The characterization of these other components, as well as their roles in colostral $\mathrm{H}_{2} \mathrm{O}_{2}$-depletion and protection of $\mathrm{HEp} 2$ cells are currently being investigated.

These studies were performed to examine further the hypothesis that human milk is antiinflammatory. They demonstrate that colostrum contains an antioxidant similar or identical to a well-recognized antioxidant component, ascorbate, which is responsible for the majority of colostral cytochrome c-reducing activity, approximately half of colostral $\mathrm{H}_{2} \mathrm{O}_{2}$-depleting activity, and very little, if any, of the protective activity of colostrum against PMN-mediated epithelial cell injury. These data support the hypothesis that human milk is antiinflammatory, and demonstrate the complexity of composition and function of human milk.

Acknowledgments. The authors thank Elizabeth Cramer, R.N., M.S., for her diligence and expertise in collecting the colostrum samples crucial for these studies, and Anne Wright for her excellent word processing.

\section{REFERENCES}

1. Goldman AS, Thorpe LW, Goldblum RM, Hanson LA 1986 Anti-inflammatory properties of human milk. Acta Pediatr Scand 75:689-695

2. Buescher ES, McIlheran SM 1988 Anti-oxidant properties of human colostrum. Pediatr Res 27:14-19

3. Boyüm A 1968 Isolation of mononuclear cells and granulocytes from human blood: isolation of mononuclear cells by one centrifugation and of granulocytes by combining centrifugations and sedimentation at $1 \mathrm{~g}$. Scand J Clin Lab Invest 21(suppl)97:77-89

4. Root RK, Metcalf $\mathbf{J}$, Oshino N, Chance $\mathrm{B} 1975 \mathrm{H}_{2} \mathrm{O}_{2}$ release from human granulocytes during phagocytosis. I: Documentation, quantitation and some regulation factors. J Clin Invest 55:945-55

5. Absolom D 1986 Basic methods for the study of phagocytosis. In: SP Colowick and NO Kaplan (eds) Methods in Enzymology, vol 32. Academic Press, Orlando, FL, p 151

6. Anderson R, Lukey PT 1987 A biological role for ascorbate in the selective neutralization of extracellular phagocyte-derived oxidants. Ann NY Acad Sci 498:229-47

7. Macy IG 1949 Composition of human colostrum and milk. Am J Dis Child 78:589-603

8. Frimer AA 1982 The organic chemistry of superoxide anion radical. In: LW Oberley (ed) Superoxide Dismutase. CRC Press, Inc, Boca Raton, FL, pp $83-125$

9. Meucci E, Martorana GE, Ursitti A, Miggiano GAD, Mordente A, Castelli A 1987 Vitamin C-bovine serum albumin binding behavior. Ital J Biochem 36:75-81

10. Dayan J, Dawson CR 1976 Substrate specificity of ascorbate oxidase. Biochem Biophys Res Commun 73:451-458 